\title{
SALT TECTONICS AND A POSSIBLE IGNEOUS ANALOGY
}

SrR,--In regions where groups of incompetent rock are interbedded with competent strata, and where large differences of density exist between the two types, crustal disturbance gives rise to rather distinctive tectonic phenomena.

Where the incompetent rock is salt, the structures present are commonly associated under the name of "salt tectonics" and include disharmonic folding, diapiric structures, thrusts, and salt plugs. Salt plugs are frequently large sub-cylindrical masses of salt which either emerge at or approach the surface, having forced their way up by gravity differential. The penetration at the surface is commonly marked by a comparatively sharp, upturned junction without any great disturbance of the surface strata for more than a short distance away from the plug periphery.

When recently considering the probable crustal fore-shortening which appears to have occurred between South Wales and the Brest Peninsula of France, due to the great movements at the end of Carboniferous time, it appeared that this fore-shortening might be in the neighbourhood of 150 miles. The general type of folding rather suggested an analogy with usual salt tectonics of a country like Iran, though on a much larger scale.

It might be possible to consider the Cornish and Devonian granite masses as due to dynamic forces familiar to those giving rise to salt plugs, in which the rise of the masses has been mainly due to the gravity difference existing between the liquid acid magma, and that of the more rigid overburden. Such a viewpoint would suggest a density difference between the overburden and the mean density of the rising magma of something in the neighbourhood of $0 \cdot 3$, with the magma being comparatively light in its molten state when containing its water vapour and gases. To what extent this magma contained sediments melted by depression to great depths during the fore-shortening is not, of course, clear, but this would not be in conflict with the point of view outlined.

With so great a fore-shortening the crustal rocks must suffer very considerable elevation or depression, and as no great elevation is suggested, depression must have taken place, but an estimate of the amount requires very much more knowledge than is at present available as to the position of possible major thrusts developed during these movements. The rather small scale puckering across the Devon peninsula rather suggests the presence of a major thrust underlying these rocks, allowing considerable movement to take place without large scale disturbance of the upper thrust sheet.

While aware of the formidable difficulties in attempting to tidy up such a hypothesis as outlined above, we feel that it might be placed before those interested in such problems for their consideration.

\section{EAKRING.}

M. W. Strong.

7th April, 1949.

\section{THE ORIGIN OF RED SANDSTONES AND CONGLOMERATES}

SIR,-I am grateful to Professor Eliot Blackwelder for the information he gave in the March-April number of this magazine about extensive alluvial fans ; but on p. 325 of my paper (1948), after citing instances, I said : "These examples of extensive fans show that such fans may have entered into the formation of the New Red Sandstone, but the absence of radial structure makes it doubtful." Owing to unavoidable delay my paper did not appear until long after the completion of the field-work on which it was based, and until after the XVIII International Geological Congress. Between two excursions when I had the privilege of demonstrating the coast-sections of New Red Sandstone in South Devon to our guests, I was able to do more field-work and subsequently deposited with the Geological Survey a chart showing the dips from Broad Sands in the south to the River Exe, also some specimens of boulders with sections, and specimens of structures I found on 
Watcombe beach during the first excursion. Of these last Dr. C. J. Stubblefield permits me to quote him as saying that the meniscus-arrangement of rock-particles suggests matter that has passed through the body of an animal, probably an annelid. They are doubtless the annelid tracks mentioned by Ussher and occur in deep red calcareous sandstone about three feet above the Watcombe Clay. Ussher, for some reason I cannot understand, included this rock with the Watcombe Clay, but it is clearly New Red Sandstone. The largest of these specimens I saw measured 14 by 1 inches. Publications show that even larger earthworms are known, but these structures are more likely to have been caused by marine or lacustrine worms on a shore ; and their position close to the Watcombe Clay, which I am now sure is weathered Devonian sedimentary rock, and their apparent absence higher up as far north as Dawlish, suggest that their disappearance was due to the amount of iron in the water.

My difficulty about accepting the alluvial fan origin of the New Red Sandstone of South Devon is that I cannot see convincing evidence of radial dips which ought to be visible in the long, clear coast-sections. Perhaps someone else may succeed where I have failed.

\section{Chaucer Road, BEDFORD. \\ 19 th June, 1949.}

J. B. SCRIVENOR.

\section{AUTHIGENIC FELSPAR IN FULLER'S EARTH}

SIR,-Dr. W. W. Black, in his letter ${ }^{1}$ on an Occurrence of Authigenic Felspar and Quartz in Yoredale Limestones, states that he is aware of only one previous record of authigenic felspars in Britain-those described by Reynolds. ${ }^{2}$ Another, however, can be mentioned. Newton ${ }^{3}$ said that the clean, flaky felspar crystals found in the Jurassic fuller's earth of Combe Hay, near Bath, and the Cretaceous earths of Nutfeld and Woburn Sands were almost certainly authigenic. Not only were the optical characters measured, but samples were separated and analysed. Both Nutfield and Combe Hay material, which were similar, suggested the composition of anorthoclase. Brammall and Leech ${ }^{4}$ said later that the felspars in the Nutfield fuller's earths were demonstrably auth genic but found that the felspar crop $(7 \cdot 2$ per cent in one of the commercial samples) was heterogeneous and the composition variable.

Not only, therefore, have we here records of authigenic felspars in fairly large percentage, but descriptions of authigenic sphene, zircon, and apatite in the Cretaceous earths, and zinc blende, zircon, and apatite in the Jurassic earth.

In all probability these fuller's earths were chemical deposits, like limestone ; under these conditions one may expect minerals beside the main ones to crystallire out. Glauconitic rocks would be expected to yield further examples. The form of the authigenic crystals is of interest in showing some characteristics of incipient crystallization as well as others of well-defined crystallinity.

\section{Botanic Crescent, \\ GLASGOW, N.W. \\ 28th May, 1949.}

1 BlaCK, W. W., 1949. Geol. Mag., 1xxxvi, 129.

2 ReYNolds, D. L., 1929 . Some new occurrences of authigenic potash felspar. Geol. Mag., lxvi, 390.

3 NEwTON, E. F., 1937. The petrography of some English fuller's earths and the rocks associated with them. Proc. Geol. Assoc., xlviii, 175-197.

4 Brammall, A., and LeECH, J. G. C., 1940. Montmorillonite in fuller's earth, Nutfield, Surrey. Geol. Mag., Ixxvii, 102-112. 